- $\quad$ Research in Language 2007, vol. 5

DOI: 10.2478/v10015-007-0003-5

Jarostaw Jakielaszek*

University of Warsaw

\title{
THE UNBEARABLE LIGHTNESS OF BEING A COPULA \\ IN LATIN: ON A TEXTUAL PROBLEM IN CICERO'S ORATION IN DEFENCE OF PUBLIUS SESTIUS
}

\begin{abstract}
:
A textual problem from Cicero's oration In defence of Publius Sestius is discussed in order to determine syntactic and semantic consequences of editorial choices. The discussion involves semantic and syntactic properties of Latin past participles within a minimalist setting. A detailed investigation of the passage indicates that a textual variant not accepted by most editors is to be preferred.
\end{abstract}

Keywords: Latin language; syntax, minimalist; natural language semantics; textual criticism; Cicero, Marcus Tullius

\section{Introduction}

Cicero's oration In defence of Publius Sestius was one of orations pronounced during the trial of Publius Sestius, accused in $56 \mathrm{BC}$ of public violence (de vi) - for political reasons, it seems - and unanimously acquitted by the jury - a witness to Cicero's outstanding expertise and oratorial ability. The case for Sestius was considerably helped by the imprudence and incompetence of the prosecutors, who incautiously used the phrase natio optimatium the race of best men', thereby giving Cicero an opportunity to expatiate on the proper understanding of the term optimates:

(1) Nimirum hoc illud est quod de me potissimum tu in accusatione quaesisti, quae esset nostra 'natio optimatium'; sic enim dixisti. Rem

* Author's address: Institute of Polish Literature, Faculty of Polish Literature and Language, University of Warsaw; e-mail: jakielaszek@uw.edu.pl 
quaeris praeclaram iuventuti ad discendum nec mihi difficilem ad perdocendum; de qua pauca, iudices, dicam, et, ut arbitror, nec ab utilitate eorum qui audient, nec ab officio vestro, nec ab ipsa causa P. Sesti abhorrebit oratio mea. Duo genera semper in hac civitate fuerunt eorum qui versari in re publica atque in ea se excellentius gerere studuerunt; quibus ex generibus alteri se popularis, alteri optimates et haberi et esse voluerunt. ['This, in truth, is the question which you put to me earnestly and most repeatedly while pleading in behalf of the prosecution, - namely, what I mean by the race of best men? For this is what you said. You ask a question which it is very desirable for the youth of the city to learn and not very difficult for me to explain, and with respect to it, I will, O judges, say a few words. And, as I think what I say will not be wholly unconnected with the advantage of those who hear me nor with my duty, nor with the very case which we are arguing of Publius Sestius. There have always in this city been two kinds of men who have been ambitious of being concerned in affairs of state, and of arriving at distinction by such a course and of these two kinds one wish to be considered popular men and the others wish both to be and to be considered of the party of the best men in the state'; Cicero, Pro Sestio $96^{1}$ ]

So begins the best known part of the speech: the so-called excursus on optimates and populares, much studied as a sort of political manifesto, foreshadowing a more elaborate treatment in Cicero's De re publica. It is clear now that the whole excursus cannot be properly appreciated if analyzed in isolation from circumstances of the trial and political situation. ${ }^{2}$ Cicero emphasizes the contrast between two political fractions at the outset; the whole excursus seems at first sight to be in fact rather extra causam, not having a direct connection to the case of Sestius. Much of the success of the defense ultimately depended on setting the stage in an impressive and effective way, and depicting the case of Sestius as a battle in a never-ending war for the welfare of the state and prosperity of its citizens. Right at the beginning, then, Cicero enumerates what forms the basis of this good condition of the republic, institutions which must be necessarily defended:

\footnotetext{
${ }^{1}$ Cicero's texts come in Yonge's translations, as listed in the references; other texts are translated by the author of the present paper.

${ }^{2}$ See recently May (2002) and Powell and Paterson (2004) for an overview of recent research on the interpretation of Cicero's orations which attempts to take into account all relevant circumstances in order to assess the rhetorical strategy properly; see also Alexander (2003) for a reconstruction of the prosecutors' case.
} 
(2) Huius autem otiosae dignitatis haec fundamenta sunt, haec membra, quae tuenda principibus et vel capitis periculo defendenda sunt: religiones, auspicia, potestates magistratuum, senatus auctoritas, leges, mos maiorum, iudicia, iuris dictio, fides, provinciae, socii, imperi laus, res militaris, aerarium. ['And of this easy dignity these are the foundations, these are the component parts, which ought to he upheld by the chief men, and to be defended even at the hazard of their lives: religious observances, the auspices, the civil power of magistrates, the authority of the senate, the laws, the usages of one's ancestors, the courts of justice, the jurisdiction of the judges, good faith, the provinces, the allies, the glory of the empire, the whole affairs of the army, the treasury'; Cicero, Pro Sestio 98]

Note that the beginning of the exposition of Cicero's political views leaves no doubts that the insitutions which are in danger and which are responsible for the well-being of the Roman state are those which have been introduced by the maiores, the ancestors - including the notoriously nebulous and vague, but always invoked with highest reverence, mos maiorum, 'the way of our elders'. This close connection between the glorious and venerable past and contemporary state of the republic is an important motive which reappears frequently, to be expressed also, as we shall see, with the use of a syntactic structure to be discussed in the present discussion.

Coming to the conclusion of this part of the speech, Cicero makes a short summary of his views, giving a brief exposition of what the optimates should do, in particular, the political institutions which should be defended, which begins as follows:

(3) Sed ut extremum habeat aliquid oratio mea, et ut ego ante dicendi finem faciam quam vos me tam attente audiendi, concludam illud de optimatibus eorumque principibus ac rei publicae defensoribus, vosque, adulescentes, et qui nobiles estis, ad maiorum vestrorum imitationem excitabo, et qui ingenio ac virtute nobilitatem potestis consequi, ad eam rationem in qua multi homines novi et honore et gloria floruerunt cohortabor. ['But in order that my speech may have some termination, and that I may cease speaking before you are weary of listening to me with attention, I will finish my argument about the party of the best men and about their leaders and about those who are the chief defenders of the republic. I will stir you up, O young men, especially you who are of noble birth, to the imitation of your ancestors and I will exhort 
you who have the opportunity of arriving at high rank by the exercise of genius and virtue to adopt that line of conduct by which many new men have become crowned with honour and glory'; Cicero, Pro Sestio 136]

Cicero's aim in the conclusion is therefore to recapitulate the correct way of handling the affairs of the republic and to exhort all to follow him and his allies in mantaining the correct constitution of the state:

(4) Haec est una via, mihi credite, et laudis et dignitatis et honoris, a bonis viris sapientibus et bene natura constitutis laudari et diligi; nosse discriptionem civitatis a maioribus nostris sapientissime constitutam. ['This, believe me, is the only path to praise, and dignity and honour, - to be praised and beloved by men who are wise and good, and endowed with good dispositions by nature; to become acquainted with the constitution of the state, as it has been most wisely established by our ancestors...'; Cicero, Pro Sestio 137]

The text as it stands in modern editions is always a result of much editorial work. Latin texts have come to us via a long chain of manuscript tradition and considerable effort is necessary to establish a sound text on the basis of manuscript readings, frequently distorted during the process of textual transmission. In the passage in question there is a divergence among manuscript readings: one of them, the codex Monacensis 15734, has the phrase a maioribus nostris sapientissime constitutam, whereas other manuscripts have maioribus nostris sapientissime constitutam, i.e. they omit the preposition $a$ 'by'. As a consequence, the nominal phrase maioribus nostris must be understood as bearing the dative case. The questions to be asked are, then, what is the difference as far as the syntax and semantics of the passage are concerned? Are they both possible in Latin? And, if so, what determines editorial choices in this case?

\section{Latin verbal system}

The clausal structure which we assume in the discussion of the passage from Pro Sestio conforms basically to the structure adopted within most minimalist thinking: 
(5)

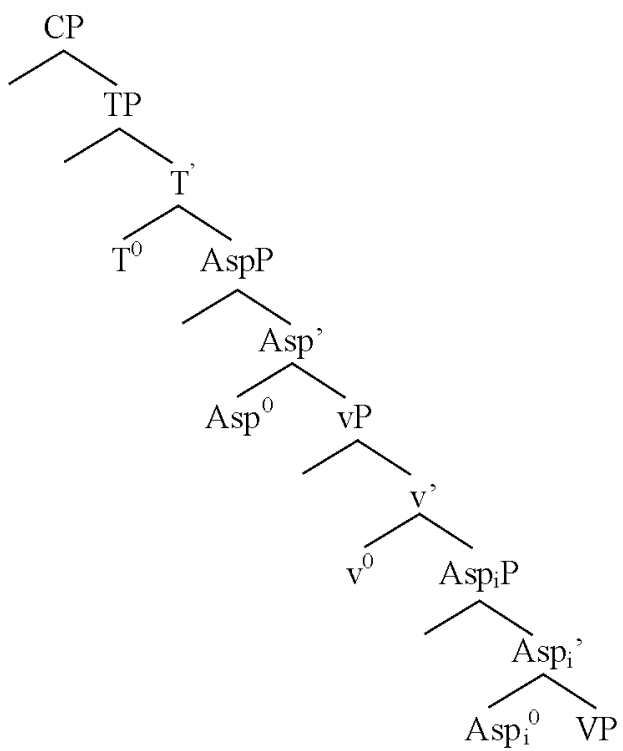

Following Pesetsky and Torrego (2001, 2004a, 2004b) and much related work, we assume the basic theta layer (VP) within the thematic layer, an (internal) aspectual projection (whose function is to give the eventuality its temporal contour) and the light verbal head projection, where the external argument is introduced. The functional layer consists of an aspectual projection (the viewpoint aspect) and a tense projection, closed by the (possibly complex) Comp-area. The compositional interpretation of the syntactic structure above the vP level in (5) makes use of the following objects (omitting the world variable for simplicity): ${ }^{3}$

(6) $\quad[[$ PAST $]]=\lambda \mathrm{p}_{\langle i, \mathrm{t},} \cdot \lambda \mathrm{t}_{0}\left[\mathrm{t}<\mathrm{t}_{0} \& \mathrm{p}(\mathrm{t})\right]$

$[[$ PRES $]]=\lambda \mathrm{p}_{\langle\mathrm{i}, \mathrm{t}\rangle} \cdot \lambda \mathrm{t}_{0}\left[\mathrm{t}=\mathrm{t}_{0} \& \mathrm{p}(\mathrm{t})\right]$

(7) $\quad[$ PERFECTIVE] $]=\lambda \mathrm{P}_{\langle 1, \mathrm{t}\rangle} \cdot \lambda \mathrm{t} \cdot \exists \mathrm{e}[\tau(\mathrm{e}) \subseteq \mathrm{t} \& \mathrm{P}(\mathrm{e})]$

[[IMPERFECTIVE]] $=\lambda \mathrm{P}_{\langle 1, \mathrm{t} t} \cdot \lambda \mathrm{t} . \exists \mathrm{e}[\tau \subseteq \mathrm{t}(\mathrm{e}) \& \mathrm{P}(\mathrm{e})]$

$\left[\left[\right.\right.$ ANTERIOR]] $=\lambda \mathrm{P}_{\langle 1, \mathrm{t}\rangle} \cdot \lambda \mathrm{t} \cdot \exists \mathrm{e}[\tau(\mathrm{e})<\mathrm{t} \& \mathrm{P}(\mathrm{e})]$

(8) $[[v \mathrm{P}]]=\lambda \mathrm{e}_{1} \cdot \mathrm{P}(\mathrm{e})$

\footnotetext{
${ }^{3}$ Assuming a standard Gallin-like typed logic with lambda-abstraction. The inventory of semantic types relevant for the discussion above includes the type e (individuals) and $\mathrm{t}$ (truth values), 1 (eventualities), i (points of time).
} 
The denotations given in (6)-(8) enable a compositional interpretation of the syntactic structure in accordance with much current theorizing about the semantics of tense and aspect (see Kratzer (1998), Stechow (1995, 2001)). Semantic tenses (type i) are analyzed as presuppositional variables (with the existential closure of the $\mathrm{t}$ variable at the $\mathrm{CP}$ level); semantic aspects relate the evaluation time to the event time as in Klein (1994). Thus, semantic aspects in above are interpreted as functions from properties of events into properties of times, requiring a verbal phrase (expressing merely an event with all its participants) as its argument and serving in turn as an argument for semantic tense. The $\mathrm{vP}$ encodes basic properties of the event, with its participants assigned relevant thematic roles within the vP. The aspectual head maps properties of events (denoted by vP, type Sl, tT) into properties of times $(\mathrm{Si}, \mathrm{tT})$. The presence of $\mathrm{Asp}^{0}$ is therefore necessary for semantic intepretation of a clausal structure: it establishes a link between the evaluation time (typically the utterance time) and the event time.

The morphology of Latin verbal system reflects quite closely the semantic makeup of the clausal building blocks. ${ }^{4}$ In matrix clauses, the semantic Present tense, when combined with the Imperfective aspect, surfaces as a form of the morphological present tense; the semantic Past tense combined with the Imperfective aspect results in the morphology of the imperfect:

(9) Marcus legit libros.

'Mark reads/is reading books.'

$\exists \mathrm{t}\left[\mathrm{t}=\mathrm{t}_{0} \& \exists \mathrm{e}\left[\mathrm{t} \subseteq \tau(\mathrm{e}) \operatorname{read}^{\prime}(\mathrm{e}) \& \operatorname{Agent}(\right.\right.$ Marc, $\mathrm{e}) \&$ Theme(books, e) $\left.]\right]$

(10) Marcus legebat libros.

'Mark was reading books.'

$\exists \mathrm{t}\left[\mathrm{t}<\mathrm{t}_{0} \& \exists \mathrm{e}\left[\mathrm{t} \subseteq \tau(\mathrm{e}) \& \operatorname{read}^{\prime}(\mathrm{e}) \& \operatorname{Agent}(\right.\right.$ Marc, $\mathrm{e}) \&$ Theme(books, e $\left.\left.)\right]\right]$

Forms built from the perfectum stem, on the other hand, result basically either from the composition of the Present tense and the Anterior aspect (the perfectum in a part of its uses; we return shortly to further details about the Latin perfect) or the Past tense and the Anterior aspect (the pluperfect):

(11) Marcus legit libros.

'Mark read books.'

$\exists \mathrm{t}\left[\mathrm{t}=\mathrm{t}_{0} \& \exists \mathrm{e}\left[\tau(\mathrm{e})<\mathrm{t} \& \operatorname{read}^{\prime}(\mathrm{e}) \& \operatorname{Agent}(\right.\right.$ Marc, e $) \&$ Theme(books, e $\left.\left.)\right]\right]$

\footnotetext{
${ }^{4}$ We omit here morphological future tenses, which arguably involve the presence of a modal operator, analogous to the WOLL operator.
} 
(12) Marcus legerat libros.

'Mark had read books.'

$\exists \mathrm{t}\left[\mathrm{t}<\mathrm{t}_{0} \& \exists \mathrm{e}\left[\tau(\mathrm{e})<\mathrm{t} \& \operatorname{read}^{\prime}(\mathrm{e}) \& \operatorname{Agent}(\right.\right.$ Marc, e $) \&$ Theme(books, e) $\left.]\right]$

In such cases the distinguished time variable $\mathrm{t}_{0}$ is interpreted as denoting the speech time and the semantic tense is interpreted with respect to the utterance time (the so-called 'absolute' use of tenses).

In dependent clauses which participate in the consecutio temporum, the morphological shape of the verbal form depends on the semantic structure of the embedding clause. This is the case e.g. in subjunctive clauses embedded under an intensional operator like verbs of saying and understanding (verba dicendi et intellegendi). It is known that infinitival constructions with a specified subject (the accusativus cum infinitivo) and subjunctive complements are equivalent in terms of temporal interpretation when embedded under such verbs. In such cases, the subjunctive forms have the same denotation as the infinitival forms: both types of clauses are similarly deprived of the deictic tense, whereas the morphology of the verbal system requires that there be a tense morphology in the subjunctive clause, which is therefore inserted in accordance with the specification of the embedding structure (which may be understood as feature transmission under c-command), whence traditional grammars characterize such forms as expressing simultaneity or anteriority with respect to the superordinate clause. This behaviour may be explained within an architecture of syntactic derivation in which the morphological component operates after the operations of the syntactic component, inserting an appropriate tense-related morphology under strict structural conditions. ${ }^{5}$ The phenomenon may be analyzed as a result of the presence of zero tense (along the lines of Kratzer (1998)), which is underspecified and therefore interpreted as the variable $\mathrm{t}_{0}$.

Morphological tenses resulting from the presence of a sequence of tense structure are therefore semantically empty: their interpretation does not correspond to their morphological shape. In structures involving embedded clauses, both the subjunctive complement and the infinitival complement clause encode the same temporal information, viz. the semantic viewpoint aspect; semantic tense is similarly absent in both types of embedded structures.

\footnotetext{
${ }^{5}$ In this way, the need to literally eliminate information provided by morphological features is avoided. It should be noted that on any formulation of the condition governing the insertion or deletion of morphological tense in the consecutio temporum environments, the operation takes place in a structure which preserves syntactic relationships, given that c-command is relevant for the operation.
} 
It must be noted that it is not simply the morphology of the matrix verb, but actual content of the $\mathrm{T}^{0}$ head which is decisive for determination of the morphology of the embedded subjunctive in such cases. Clear evidence is provided by cases in which the morphological shape may correspond to various tense + aspect combinations, as is the case with the perfect tense. Latin perfectum may contain the semantic Present and the Anterior aspect; yet it is also frequently a spell-out of the composition of the semantic Past tense and the Perfective aspect, which has visible consequences for the consecutio temporum:

(13) Iam quantum consilio [...] valeat [...], vos, Quirites, hoc ipso ex loco saepe cognostis. ('How great his wisdom is, [...], you, O Romans, have often experienced yourselves in this very place'; Cicero, Pro lege Manilia 42)

(14) Vidi enim et cognovi quid maxime spectares. ('For I have seen and known what it was that you mainly considered'; Cicero, Pro Ligario 31)

A semantically tenseless complement embedded under a semantic past tense is interpreted as simultaneous with an event located in the past (the event expressed by the matrix clause). The difference in surface realization of the embedded verb follows form the tense-aspect combination in the matrix clause: if the matrix $\mathrm{T}^{0}$ contains the Past tense, the tense morphology on the embedded subjunctive follows the tense of the matrix clause (resulting in Past + Imperfective in (14) above, i.e. the subjunctive imperfect); if the matrix structure contains the semantic Present tense, however, a different morphology of the embedded subjunctive emerges, as in (13), where the subjunctive present in the embedded clause follows from the presence of the Present tense in $\mathrm{T}^{0}$ of the matrix clause. Although in both cases the matrix clause includes a morphological past tense, the sequence of tenses is sensitive to its semantic composition, not simply the surface shape, the semantic tense of the matrix clause determining the ultimate morphological shape of the embedded subjunctive. Thus, the morphological spell-out of semantically tenseless verbal forms in embedded structures depends directly not on the morphology of the embedding verb, but on its semantic composition.

Importantly for the present case, the morphology of Latin perfectum may also hide yet another semantic specification. In some cases, neither the combination Past + Perfective nor Present + Anterior is able to explain 
the presence of a form built from the perfectum stem. This is particularly clear in examples with embedded clauses, either infinitivals (which lack tense morphology entirely) or subjunctives (which is the reason of the foregoing discussion of the consecutio temporum). Consider the following examples:

(15) Corinthum patres vestri, totius Graeciae lumen, extinctum esse voluerunt. ('Your ancestors determined that Corinth, the light of all Greece, should be destroyed'; Cicero, Pro lege Manilia 11)

(16) Iustitia restat, ut de omni virtute sit dictum. ('To have all virtues discussed, there remains justice'; Cicero, De finibus 1.50)

In both (15) and (16) the embedded structure is semantically tenseless: an infinitival in (15), a subjunctive in a final clause in (16). Neither in (15) nor in (16) may the embedded structure express anteriority - on the contrary, the semantics of the verb velle 'want' and of the final complementizer $u t$ 'in order to' forces an interpretation in which the eventuality described by the embedded clause follows the eventuality denoted by the matrix. As the example (16) clearly demonstrates, it cannot be the case that any sort of attractio temporis, a purely morphological operation which would obliterate syntactic and semantic relationships between clauses and annihilate the operation of consecutio temporum, could be responsible for the morphology of the verbal form in the embedded clause: the matrix verb carries morphology of the present tense, and the morphology of perfectum in the embedded clause arguably results form the usual copying of the matrix present, i.e. from the operation of consecutio temporum. Similarly, in (15) it is possible to replace the perfectum form voluerunt '(they) wanted' with a form containing unequivocally the Present tense, e.g. volunt '(they) want, without chaning morphology of the embedded verb. As noted, though, the embedded forms cannot contain the semantic Anterior aspect. The morphology of perfectum must follow from the presence of another component. In fact, semantics of embedded clauses in such cases is distinct from cases in which there would be only a semantic aspect (not the Anterior) present. Were we to put instead of the infinitivus perfecti passivi a form typically occurring in such contexts, i.e. an infinitivus praesentis like exstingui 'to be destroyed', the embedded clause merely denotes an eventuality which must occur in the time span whose left boundary is set by the semantic content of the matrix clause (in the case we put there an infinitivus futuri, the event is located in the future 
only more explicitly). More strictly, the infinitival is interpreted as eventive - unless an unescapably stative verb is inserted in the infinitival structure, the most obvious interpretation is that there is an event which is going to take place. In sentences with a form of the perfectum, on the other hand, the embedded clause is interpreted as stative: there is a state, which results from a prior action (taking place earlier than the state obtains, of course, but not explicitly ordered with respect to the semantic tense of the matrix clause) and which is expected to hold in the future. It seems, then, that it is a sort of a stativizing element which is responsible for the semantics of such structures and for the morphology of the verbal form.

Let us therefore assume that a head with semantics along the lines proposed in much current work on resultant states may be present within the Latin verbal phrase as well, being responsible for the perfectum forms in a part of their uses. Apart from the combinations Present + Anterior and Past + Perfective, the morphology of the perfectum in Latin may therefore be an exponent of the complex Present + Imperfective + a stativizer. For concreteness, suppose that the stativizing head takes as the input properties of events and turns them into properties of states:

$$
[[\mathrm{STAT}]]=\lambda \mathrm{P}_{\langle 1, \mathrm{t}\rangle} \cdot \lambda \mathrm{s} \cdot \exists \mathrm{e}[\operatorname{Result}(\mathrm{s}, \mathrm{e}) \& \mathrm{P}(\mathrm{e})]
$$

The semantics in (17) forces low insertion of the stativizing head in the clausal tree: it must be attached lower than the semantic aspect, given that the latter turns properties of eventualities into properties of times, constituents of an inappropriate logical type for the stativizer to operate on. We return to various possible attachment sites later on; for now suppose that the stativizer in (15) operates on the entire vP, i.e. also on the $v^{0}$ head (of the passive type, i.e. with an implicit agent, existentially closed at the vP level). A simplified semantic representation of the embedded infinitival in (15) would look roughly as follows:

$$
\begin{aligned}
& \lambda \mathrm{t}_{0} \exists \mathrm{s}[\tau(\mathrm{s}) \supseteq \mathrm{t} \& \exists \mathrm{e}[\operatorname{Result}(\mathrm{s}, \mathrm{e}) \& \operatorname{destroy}(\mathrm{e}) \& \exists \mathrm{x}[\operatorname{Agent}(\mathrm{e}, \mathrm{x}) \\
& \text { \& Theme(e, Corinth)]]] }
\end{aligned}
$$

When combined with the matrix clause, the embedded infinitival denotes a state expected to obtain in the time span beginning with a time which is anterior with respect to the utterance time (i.e. a 'future in the past' - the matrix Present + Anterior establish the relevant semantics). Crucially for the 
present case, the state is a result of a prior event in which Corinth suffers destruction. That seems to represent correctly relevant aspects of the semantics of $(15){ }^{6}$

\section{Participles: Stative and Anterior}

In order to choose one of two transmitted readings of the passage in (4), the structure and semantics of the passage must be carefully examined. As noted above, the reading preserved in the majority of manuscripts contains a dative case marked nominal maioribus, rejected by most editors, who adopt reading present in one manuscript only, viz. an ablative a maioribus. The difference between the two options consists in precise understanding of the semantics of the participle constitutam, morphologically a so-called participium perfecti passivi, which appears in analytic verbal forms built from the perfectum stem. It has been long observed that Latin analytic passives may be divided in two main groups: one, filling the place of the eventive passive in the verbal paradigm in cases when a synthetic verbal form is unavailable as a language-particular morphological peculiarity (i.e. in all forms built from the stem of the perfectum); and a second one, which corresponds to the German Zustandspassiv and displays stative semantics:

(19) Discriptio civitatis constituta est.

'The constitution of the state has been established.'

(20) Discriptio civitatis constituta fuit.

'The constitution of the state was in a state of having been established.'

There is a clear indication that participles in the eventive passive involve the functional structure up to the viewpoint aspect layer: the verb esse, which appears in such structures as the auxiliary, is allowed to take only either the present tense form (in which case a form of perfectum is built) or the imperfect tense form (which results in a pluperfect). This is an indication that the participle includes as much as the semantic Aspect:

\footnotetext{
${ }^{6}$ It should be noted that with a stative semantics as in (15), analytic verbal forms are preferred in the Classical Latin. Synthetic verbal forms of the perfectum stem are avoided, probably due to a conscious effort to reduce morphological ambiguity in this case - with analytic structures, an ambiguity between eventive and stative passives is well-established and may be frequently removed thanks to other devices to which we return.
} 
(21)

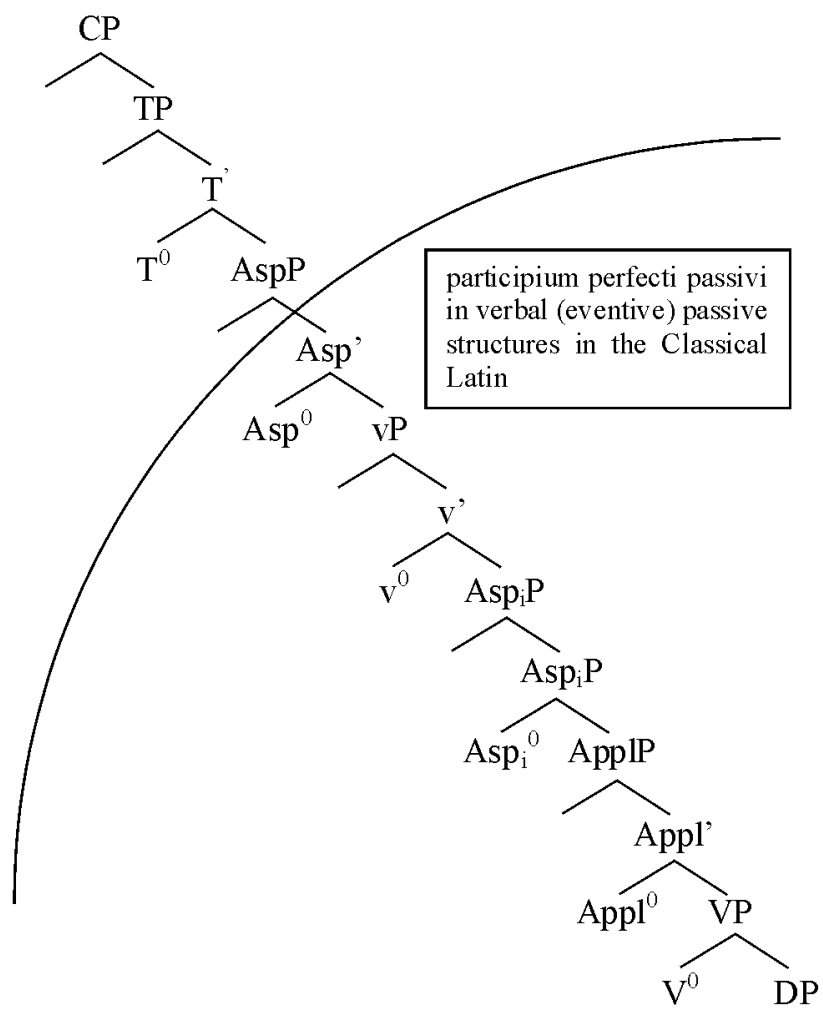

This behaviour fits with the idea that the verb esse as an auxiliary in eventive passive structures is a spell-out of the $\mathrm{T}^{0}$ head - recall that the inventory of semantic tenses assumed in (6) above included only the Present and the Past; the aspect Anterior is therefore located in the participle in eventive passives. The stative passive, on the other hand, allows all forms of the verb esse. The distinction between the verbal (eventive) and stative passive is blurred in analytic verbal forms, where no morphological distinction is observable and only semantic decomposition provides clues as to the actual content of specific functional heads. Of course, structures containing present or imperfect forms of the verb esse are also ambiguous - as Madvig (1842: 219) put it, nec enim Latinus sermo praeteritum tempus rei gestae et praesens rei agendo effectae et in statu aliquo manentis nota ulla distinguit ('Latin does not distinguish in any way the past tense expressing a past action and the present tense expressing a current state resulting from an anterior action').

In some cases, the difference is visible because of the use of the dativus auctoris instead of ablativus auctoris (a prepositional phrase) with the stative. 
Traditional classifications of various uses of nominal phrases marked with the dative case in Latin typically reduce different instances to the basic meaning of an affectee (beneficiary or adversely affected), seeking to estabish a common semantic core and ignoring possible structural differences, not surprisingly given that conceptual apppartaus of the traditional grammar does not allow fine structural distinctions. The two ways of referring to an agent of the eventuality are perceived as not entirely equivalent, however: the ablativus auctoris is taken to refer to the agent without any semantic overtones; the dativus auctoris, on the other hand, is typically explained as originating form the semantic function of the affectee (see e.g. the discussion in Ernout and Thomas (1964: 74-75)). It is to be noted that the dativus auctoris is still distinct from argumental beneficiary datives of the kind appearing with ditransitive verbs, where the meaning of the affectee is quite clear and no implication of agency is involved. Following much recent work on applicative structures, suppose that the dative in ditransitive structures is an argument of a low applicative head, which relates two arguments and the verbal root: whereas the dativus auctoris, a non-obligatory element present in stative passives, enters the structure as the specifier of a high applicative head, which relates an individual referred to by the dative case-marked nominal and the lower eventuality (along the lines of Pylkkänen (2002)). The dativus auctoris is a typical way of referring to the agent with stative passives, in contrast to eventive passive, which typically use the prepositional ablative. ${ }^{7}$ The choice between the two readings in (4) above seems to be essentially a choice between an eventive reading of the participial and a stative one.

The proposal to introduce a stativizing result operator, discussed above, affects also our analysis of participial strucures. Departing form earlier proposals to distinguish between verbal and adjectival participles on the basis of their place of origin - Lexicon in the adjectival case, syntax in the verbal case $^{8}$ - Embick (2004) proposes to derive all participal strucures in the syntax, distinguishing three types of so-called past participles: a verbal type (Eventive Passive in Embick's terms) and two types of non-verbal forms:

\footnotetext{
${ }^{7}$ Another environment in which dativus auctoris frequently appears - indeed, a canonical one for most descriptive grammars - is the so-called coniugatio periphrastica passiva, where a form of the verb esse is coupled with the gerundivum, expressing an obligation to do something. We shall address briefly such structures below.

${ }^{8}$ For an influential discussion, see Wasow (1977), in a discussion with (Freidin 1975). The two-place approach has been recently revived in a different setting in Horvath and Siloni (2005).
} 
Stative and Resultative. A structure with a full array of verbal functional heads is assigned to verbal participials, as in (22) below:

(22) The door was opened/closed. ('someone opened the door')

A functionally impoverished structure, where an aspectual head (dubbed 'Asp-S', i.e. a head which appears in statives) attaches directly to a root structure, is assigned to adjectival participles (possibly morphologically distinct from the other two due to this structural difference):

(23) The door was open/closed.

Yet another structure, on the other hand, underlies, according to (Embick 2004), stative uses of the past participle in which there is an implication of a prior event, i.e. resultative participials:

(24) The door was opened. ('the door was in a state of having become opened')

Resultative participles of the type exemplified in (24) are analyzed in Embick (2004) as involving an aspectual head Asp-R (i.e. a 'resultative' aspect), which takes as a complement a vP structure headed by the light verbal head $\mathrm{v}^{0}$ with feature specification Fientive (i.e. a sort of the BECOME-operator).

Since Embick (2004) is primarily interested in syntax-morphology relationships, semantic properties are not discussed in much detail, nor is the distinction between target states and resultant states examined. This has been done in Anagnostopoulou (2003), who elaborates on the work of Kratzer and extends the discussion to cover Modern Greek data. A detailed analysis of the behaviour of Modern Greek participles indicates that there are important differences with regard to stativized structures in resultative constructions. Consider the following examples (from Anagnostopoulou 2003: 18):

(25) To psari itan tiganismeno apo tin Maria. the fish was fried by the Mary 'The fish was fried by Mary.'

(26) *Der Fisch war von Maria gebraten. the fish was by Mary fried 
'The fish was fried by Mary.'

(27) I porta itan anigmeni apo tus astinomikus. the door was opened by the policemen

'The door was opened by the policemen.'

(28) *Die Tür war von den Polizisten geöffnet. the door was by the policemen opened

'The door was opened by the policemen.'

German resultative statives do not allow a prepositional phrase expressing the agent of the eventuality; Modern Greek, on the contrary, freely allows them. Anagnostopoulou (2003), applying also other tests, concludes that the structure which may be stativized in Greek is larger than in English or German case: the stativizer is attached below the vP level in German, which excludes insertion of the head $\mathrm{v}^{0}$ with a featural specification related to an event - only a stative $\mathrm{v}^{0}$ (by definition without any reference to the Agent theta role) is possible. Greek, on the other hand, stativizes the whole (eventive) vP, whence prepositional agents are possible. The difference is explained as resulting from different selectional properties of the stativizer in English/German and Modern Greek. We return to the point shortly; for the time being observe that the behaviour of stative passives in Latin resembles the English/German case. Suppose, then, that in Latin stative passives the stativizer may appear only below the vP level.

A further distinction concerns target state vs. resultant state structures. Anagnostopoulou (2003), building on the discussion in Kratzer (2000), who develops the theory of target vs. resultant state passives in some detail (see Parsons (1990) for the original statement of the idea of target states as distinct from resultant states), proposes that their different properties follow from differences in the attachment site of the stativizer: lower in target state participles, higher in resultant state ones. Within a slightly different framework of assumptions - in particular, assuming that syntactic structure does not contain purely category-defining heads and that the light verbal head $\mathrm{v}^{0}$ is not different from the Voice head - suppose that, beside structures in which the root is already defined as denoting a state, a stativizing operation may affect either the basic thematic layer or a larger chunk of the structure. In the former case, a target state participial emerges. The stativizing operator may also attach higher; given its semantic type, AspP (within the vP) and the whole vP are all possible attachment sites (we return to the case of stativizing the whole $\mathrm{vP}$ shortly): 
(29)

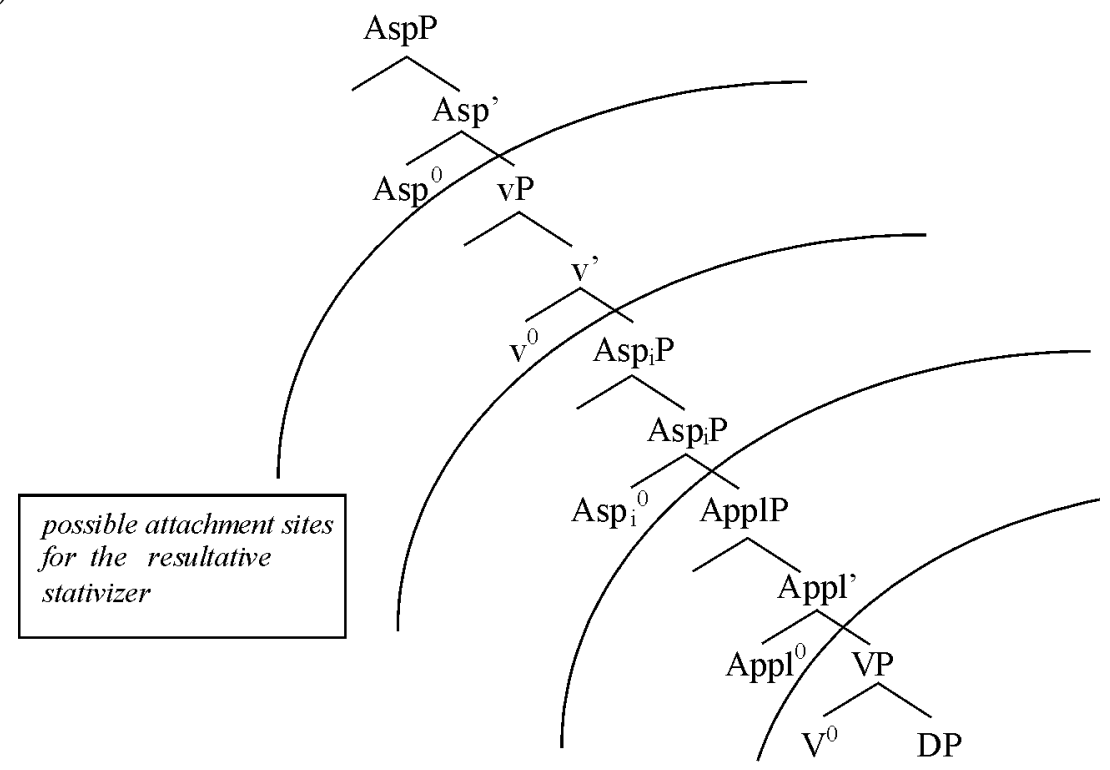

The difference in interpretive properties does not follow, we assume, from different semantics of the stativizer (recall that Kratzer (2000) proposes for resultant statives a head with semantics essentially equivalent to the semantic Anterior aspect), but from differences in the semantic specification of the stativized structure: in the case of resultant state participles, the event together with its temporal contour is defined, in contrast to target state participials, where all information provided by functional heads is related to the state, not to the foregoing event.

The presence of high applicative datives is also expected on this account - the stativized structure includes the argumental layer of the clause. Depending on the precise attachment site, dative nominal phrases may refer to individuals related via the high applicative head to the state resulting from some prior event, if the stativizer is attached below the Appl ${ }^{0}$. In such cases, one might expect that the most prominent aspect of the semantic interpretation is that of being affected as a holder of the state. If the stativizer appears above the high applicative head, the nominal denotes an individual which is related to the event (i.e. not the state which follows), whence an agentivity implication is more probable.

Latin participium perfecti passivi may be therefore assumed to incorporate the Result operator, beside being able to take part in the formation of the perfect passive infinitive. The meaning of such structures is derived in 
a compositional way from the meanings of constituents. The upper part of the participial structure is deprived of any information about aspect or tense; the presence of the resultative operator attached low in the tree provides appropriate resultative meaning, without any reference to the speech time.

As for the adjectival use arising from the lowest possible attachment of the stativizer, i.e. immediately above the VP, Madvig (1842: 224) comments as follows: Videntur [...] interdum participia quaedam deponentium et passivorum sic potuisse poni, ut [...] condicionem et statum significarent, paene in adiectivi notionem transeuntia, deinde verbum adiungeretur per se praeteriti forma ('it seems that it was possible to use some participles of deponent and passive verbs in such a way that they expressed a condition and state, coming close to being adjectives, and then the verb was adjoined, being by itself in a preterite tense'). Such cases are recorded in descriptive grammars as 'peculiarities' of the participial syntax (see e.g. Menge (2000: 711)), which is due to the established view that the principal meaning of the participium perfecti passivi encodes anteriority. This view is strenghtened by the fact that writers of the Classical Latin tend to make various aspects of syntax and semantics more regular, and the absence of several structures in Caesar and in Cicero is to be explained as a result of a tendency to avoid structures which are ambiguous as far as the relationship between the surface shape and its underlying semantic and syntactic properties is concerned.

\section{Lightness of the Copula}

The discussion above may lead to a tentative answer to the question about correctness of the two manuscript readings of the passage from Cicero's text: it may seem that there is a choice between the verbal form, encoding anteriority (as a result of incorporation of a semantically contentful Asp ${ }^{0}$ head specified as Anterior aspect) and requiring the nominal phrase to appear in a prepositional structure (a maioribus nostris) which denotes the agent of the event; and the stative participle, expressing a state resulting from an earlier eventuality - i.e. an action undertaken by the ancestors - and necessarily combining with a dative case marked nominal (maioribus nostris), whose semantics varies depending on the actual specification of the (high) applicative head, thereby resulting in a mixed affectee/beneficiary meaning (with an implication of agency). The answer seems to depend on the understanding of the whole passage and Cicero's intentions: does 
he merely want to say that the ancestors established the state as such-an-such, or is there in fact a stress on the fact that the constitution of the state as established by them continues to function in Cicero's times? Yet the situation is not so clear. All structures examined above involve a full clausal structure with both the predicate and the copular element expressed overtly; in the Ciceronian passage, on the contrary, the participle does not appear in a fullfledged clause. Before concluding along the lines suggested above, possible differences in behaviour of participles in different environments must be investigated. It turns out that such differences do in fact exist.

It should be noted that participles appearing outside copular clausal structures exhibit more freedom with respect to the tests for the presence of a semantically contentful (i.e. introducing an implicit agent) light verb head (the examples are from von Stechow 1998):

(30) der vor 3 Tagen (von Ede) reparierte Computer the before 3 days (by Ede) repaired computer

(31) der seit 3 Tagen reparierte Computer the since 3 days repaired computer

Beside the adjectival passive interpretation in (31) - which, in German and Latin alike, does not allow the presence of an implicit agent - there is also an interpretation which admits the agent to be even overtly expressed, as in (30). Latin participium perfecti passivi as an attributive adjective appears also as involving the Anterior aspect; it may also however convey a stative meaning, in which case there may be an implicit agent:

(32) Quodvis potius periculum mihi adeundum quam a sperata dicendi gloria discedendum putavi. ('I thought it was necessary to undertake rather any risk than to abadon the hope for the glory'; Cicero, Brutus 314)

(33) Cuius [scil. Archimedis] ego quaestor ignoratum ab Syracusanis [...] indagavi sepulcrum. ('I found his [i.e. Archimedes'] tomb, unknown to Syracusans'; Cicero, Tusculanae disputationes 5.64)

It must be noticed that an implicit agent need not be necessarily present when the participium perfecti passivi appears as an attributive adjective; yet clear cases in which an agent is semantically present suggest that it is in principle possible to stativize with the aid of the resultative operator a full verbal phrase which contains semantic features encoding the presence of an agent of the event. Thus, in (32) it is not the case that anyone might be the person who hoped to gain an immortal glory as an orator; 
in (33) the agent is even overtly expressed by the PP ab Syracusanis 'by the Syracusans'. The behaviour of the participium perfecti passivi in its attributive uses points to a possibility that it is not the size of the constituent which undergoes stativization that is responsible for the absence of agentive $a b$-phrases with the stative adjectival passive. A solution which would rely on selectional properties of the stativizer and cross-linguistic variation in this regard would leave the behaviour of the participials in (32)-(33) unexplained.

Another environment in Latin in which we should be able to detect possible relevance of the presence of the verb esse 'to be' for availability of participial constructions is the so-called ablativus absolutus: a participial structure which is arguably a clausal structure, semantically equivalent to a full-fledged adjunct clause. ${ }^{9}$ The participium perfecti passivi appears here most frequently with the Anterior meaning, therefore incorporating the Asphead. There are quite numerous examples, however, in which the participium perfecti passivi does not express anteriority, but is rather a resultative participle (see Menge (2000: 710)). This much can be expected given that also in clausal structures with the verb esse the participial morphology may be used to convey a stative meaning. Crucially for the present case, in absolute participial structures which are stative there may be an implicit agent - we might expect it to be expressed overtly with the use of the agentive $a b$-PP (i.e. the equivalent of the $b y$-phrase), were it not the case that in such cases the subject of the matrix clause is the same as the implicit agent of the participial structure, whence its overt presence is attested only in relatively rare instances of contrastive focus (see Kühner and Stegmann 1912: 772 f.).

The behaviour of the participium perfecti passivi outside structures containing a form of the copular verb esse 'to be' suggests that it is possible in Latin to stativize a vP with the light verb head containing features related to the agent provided that there is no subsequent insertion of the verb esse 'to be'. Suppose, then, that the verb esse 'to be' cannot be inserted in the morphological component as a realization of a head chain which includes an agentive light verb. In the case of the verbal passive, the auxiliary lexicalizes $\mathrm{T}^{0}+\operatorname{Mod}^{0}$ heads, whereas the participle covers all verbal heads which appear below in the structure. In adjectival passives, the situation differs: the verb esse is inserted as a copula, which forces it to include the verbal chain down to the light verb $v$. If language-particular

\footnotetext{
${ }^{9}$ Ablativi absoluti should be regarded full CPs, not reduced structures deprived of higher functional projections, witness their clausal semantics and the occurrence of various adverbial particles belonging to the Comp-area like utpote or quippe 'inasmuch as', 'since' etc. which appear also in the Comp-area of 'regular' subordinate clauses; see Kühner and Stegmann (1912: 789 ff.).
} 
setting of the morphological component precludes its insertion when the light verb encodes features related to agentivity, the only structures available as adjectival passives involve the stativization below the $v \mathrm{P}$ level.

A cursory look at cross-linguistic evidence suggests that the morphological parameter as stated above is too strong. The verbal element 'to be' is not necessarily excluded as an overt lexical item in all contexts where an agentive light verb appears; it seems that this is the case with the so-called 'agentive be' as exemplified by well-known contrasts below:

(34) a. Mary made Jane polite.

b. Mary made Jane be polite.

(35) a. John is noisy.

b. John is being noisy.

Examples in (34)-(35) provide instances of the agentivity effect (in infinitival clauses and the progressive respectively), which seems to be due to the presence of the verb be: in both (b) sentences, there is an implication that the subject is an agent of some eventuality, in contrast with the (a) sentences, which contain just bare predication of a property. Such examples led to postulation of an agentive verb to be, which turned useful in accounting for some properties of the set in (36) below:

(36) a. John is hard to please.

b. It is hard to please John.

c. John is being hard to please.

d. *It is being hard to please John.

It has been argued in Partee (1977) that the unacceptability of expletive subjects in the progressive structure in (36) $\mathrm{d}$. above follows from the existence of an 'active verb $b e$ ' (with a meaning similar to 'act'), which does not discharge its theta-role when an expletive is inserted; whereas in the nonprogressive counterpart there is a verb of predication, which does not possess any agent-related (or more broadly, any theta-related) features. Put in more current terms, the agentive be is a spell-out of a verbal head chain which has a theta-role to discharge - the Agent theta-role ${ }^{10}$. Assuming correctness of the basic line of Partee's proposal, ${ }^{11}$ the existence of the agentive be falsifies

\footnotetext{
${ }^{10}$ Differences between the original claim made in Partee (1977) and its reformulation given above are obvious, stemming from the general difference between lexicalist and non-lexicalist approaches.

${ }^{11}$ Let it be recorded that the debate over the existence of the agentive be remains open; see e.g. Déchaine (1993), Rothstein (1999) for various criticisms against Partee's proposal.
} 
the claim that it is impossible - as a consequence of a language-specific parameter setting - to insert the verb be in English as a realization of a chain containing a semantically active Agent theta-feature.

The hypothesis put forth in the preceding paragraph implies that there is a dissociation between the participial form and the agentive semantics in cases when a given language permits stativization of the vP in clauses with the copula. In fact, most analyses assume that there is a correlation between the height of attachment of the stativizing operator and the size of the structure which comes to be realized as a participle. Such close connection is justifiable in the case of nominalizations, as witnessed in recent work on nominalized structures in various languages. In such cases, it seems reasonable to assume that a nominalizing head, which changes the categorial status of the embedded structure, has a morphological reflex at the attachment site. Yet the situation with stative passive structures is different in an important way: there is no category-switching in the clausal spin, the whole structure remains clausal from bottom to top. ${ }^{12}$ Semantic differences follow from different featural makeup of functional heads which constitute the structural skeleton of the stative passive in its various incarnations; the presence of a resultative stativizer ensures that the ultimate meaning of the structure involves appropriate semantic features; it does not necessarily mean, however, that the morphological component inserts a participial morpheme exactly where the stativizer is inserted - which would require us to assume that the semantics of a stativizer gives the meaning of the participle-forming morpheme. This approach is developed in Paslawska and Stechow (2003), who explicitly state that past participles "can also be formed in the syntax by attaching the functional category Part to a passivized VP [...] The participle head introduced in the syntax has a constant meaning, which may be called grammatical meaning." Paslawska and Stechow (2003: 344). This assumption is hardly escapable in a framework which tends to tie particular morphemes with specific heads. Notice, though, that the relationship between morphological items and

\footnotetext{
${ }^{12}$ The assumption that the structure is unequivocally clausal in stative passives is not uncontroversial; in particular, much depends on precise understanding of the role and place of functional heads which are supposed to be responsible for categorial properties of syntactically derived objects - were we to assume e.g. that there must be a little $a^{0}$ for adjectival properties to emerge, the structure becomes different from the structure of clauses with purely verbal predication - a hypothesis presented by e.g. Anagnostopoulou (2003). Yet if we adopt some version of the category-less syntax, in which behaviour typically attributed to the categorial specification follows from more general principles, such a conclusion is not necessary, and clauses containing participials need not differ from 'verbal' ones in terms of syntactic heads building the clausal structure; in fact, we would maintain that there is even a possibility of variation with respect to morphological realization depending on language-particular settings of the morphological component.
} 
syntactic structure became more loose with the progress of the work within the minimalist framework, from strictly lexicalist assumptions of the Minimalist Program and morpheme-based incarnations of Distributed Morphology - as clearly visible e.g. in Marantz (2001), who explicitly refers to the attachment of a passive/stative suffix, equating the chunk of the structure which is spelled-out as a participle with the structure embedded under a stativizer - to a much more flexible nanosyntactic approach. In particular, it might be assumed that the stativizer under discussion does not necessarily enter the derivation as a separate syntactic head: it may come bundled with other syntactic heads, in the manner suggested for the causative element in Pylkkänen (2002). On a more empirical side, it must be noted that the presence of the resultative stativizer does not entail participial morphology in Latin verbal system. Synthetic verbal forms built from the perfect stem may be semantically divided into two basic classes, corresponding to the division between verbal vs. adjectival passive, yet without morphological effects which might be attributed to the stativizing head. It is therefore justified not to establish too close relationship between the presence of the participial morphology and the stativizer.

An additional remark is necessary about the coniugatio periphrastica passiva, allowing both the dativus auctoris and the prepositional ablative and arguably involving an adjectival form (the gerundivum). Such constructions, beside expressing the agent with the dative case marked nominal phrases, allow also quite frequently the ablativus auctoris (see Lebreton 1901). Both gerundial forms - the gerundivum as exemplified above, and the gerundium, i.e. a deverbal noun which preserves verbal properties with respect to argument licensing - appear without overt nominals bearing the Agent theta role; this happens when they appear in complement positions and in adjunct positions as well. The last case is particularly visible in the ablative of the gerund, an adjunct expressing manner, cause etc., where - despite absence of an overt agent-denoting nominal, there is clearly an active $\mathrm{v}^{0}$ head. On the movement-based account of control phenomena, either raising to the main clause must take place or - if it is impossible for syntactic reasons - a covert pronominal with an impoverished specification is inserted in the structure. Of crucial importance for determining the actual content of gerundial ablatives are (non)coreferentiality effects. At first sight, the ablative of the gerund requires coreferentiality with the matrix clause subject. This is indeed frequently the case in the Classical Latin:

(37) Delatum est ad vos, pontifices, [...] quem ad modum iste praeposteris verbis, ominibus obscenis, identidem se ipse revocando, dubitans, timens, 
haesitans omnia aliter ac vos in monumentis habetis et pronuntiarit et fecerit. ['It was then reported to you, O priests, [...] how he, with preposterous language with ill-omened auspices, at times interrupting himself, doubting, fearing, hesitating, pronounced and did everything in a manner wholly different from that which you have recorded as proper in your books'; Cicero, De domo sua 140] ${ }^{13}$

Several instances may be found, though, where the coreferentiality is absent (see further Lebreton (1901: 394)).

(38) Deinde vestra responsa atque decreta et evertuntur saepe dicendo et sine defensione orationis firma esse non possunt. ['In the next place, your replies and your decisions are constantly overturned by eloquence, and cannot be made firm except by the advocacy of the orator'; Cicero, Pro Murena 29]

Given the fact that there is no requirement of coreferentiality between the external argument of the gerundial and any argument of the main clause - witness the example cited above - the structure should be most plausibly analyzed as involving the non-obligatory control, i.e. an empty underspecified pronominal as the thematic subject of the gerundial clause. ${ }^{14}$

We tentatively propose that the coniugatio periphrastica passiva is also in fact a biclausal structure, with a phonologically null modal operator in the embedded participial clause. The whole structure is then built along the lines suggested in Bhatt (1998). This would explain why prepositional ablative agents are available for such structures much more easily than with monoclausal stative passives: the structure in reality involves a clausal layer in which only an adjectival form, the gerundivum, is inserted as an overt item, hence there is no clash with requirements of the verb esse if a head with a specification for the Agent theta role (a passive light verb $v^{0}$ ) appears in the lower clause, analogous in this respect to the participial in (4).

${ }^{13}$ The text of the manuscripts has been changed here by Madvig, who found the sequence revocando, dubitans, timens, haesitans suspect and emended accordingly revocando to revocans (explaining the mss. reading as resulting from dittography). His conjecture has been subsequently accepted by most editors, yet Maslowski in his Teubnerian edition does not introduce it into the main text, relegating the Madvigian reading to the apparatus (with a cautious remark fortasse recte 'perhaps correctly').

${ }^{14}$ For a different proposal, see Miller (2000), who assumes the presence of PRO in the specifier of the verbal phrase in gerundial structures, which is intended to explain the impossibility of an overt lexical subject. The restriction follows from specific assumptions about Case assignment in nonfinite structures; see Miller (2000) for a detailed discussion. 


\section{Conclusion}

The passage which opens the summary of Cicero's views on the political situation and duties of 'good citizens', cited in (4) above, goes on as follows:

(39) Qui [scil. maiores nostri] cum regum potestatem non tulissent, ita magistratus annuos creaverunt ut consilium senatus rei publicae praeponerent sempiternum, deligerentur autem in id consilium ab universo populo aditusque in illum summum ordinem omnium civium industriae ac virtuti pateret. Senatum rei publicae custodem, praesidem, propugnatorem conlocaverunt; huius ordinis auctoritate uti magistratus et quasi ministros gravissimi consili esse voluerunt; senatum autem ipsum proximorum ordinum splendorem confirmare, plebis libertatem et commoda tueri atque augere voluerunt. Haec qui pro virili parte defendunt optimates sunt, cuiuscumque sunt ordinis. ['Who [i.e. our ancestors], when they could no longer endure the power of a king, created annual magistrates on the principle of making the senate the perpetual supreme council of the republic, and of allowing men to be elected into that body by the whole people, and of opening the road to that supreme order to the industry and virtue of all the citizens. They established the senate as the guardian, and president, and protector of the republic; they chose the magistrates to depend on the authority of this order, and to be as it were the ministers of this most dignified council; and they contrived that the senate itself should be strengthened by the high respectability of those ranks which came nearest to it, and so be able to defend and promote the liberties and interests of the common people. Those who defend these institutions with all their might are the best men, of whatever rank they are'; Cicero, Pro Sestio 137-138]

Cicero describes all elements of the constitution of the state which he considers relevant for the characterization of the 'best state'. This is done as an enumeration of actions undertaken by the ancestors - a sequence of the perfectum forms creaverunt conlocaverunt ... voluerunt '(they) created ... established ... wanted' (the last verb translated above differently to suit the needs of the English sentence), containing the semantic Past tense, witness the preterital consecutio visible in forms of embedded subjunctives praeponerent lit. '(they) have placed in front' etc., resulting from a morphological copying operation of the Past from the embedding clause. Thus, the activity of the ancestors is unequivocally located in the past. What is the connection with the state of affairs as seen by Cicero? The whole passage is followed by an 
explicit reference to the present - the form defendunt '(they) defend' leaves no doubt that the effects of past constitutional activities must still endure. It seems that the beginning should also provide such reference to the contemporaneous situation, this time via a resultative participle: its semantic specification ensures that the state denoted by the participle is interpreted as simultaneous with the verb nosse 'know', which is itself in turn a resultative infinitive. The perfectum forms of the verb nosco (in fact an inchoative formation), i.e. novi 'I know' are singled out in descriptive grammars as belonging to the class of the so-called perfecto-praesentia, i.e. verbs which possess only forms built from the perfectum stem 'with the meaning of the present' - in other words, resultative perfects. The temporal anchoring is provided by the verb est 'is' in a present tense form. Thus, both the knowledge and the state resulting form earlier undertakings of the ancestors are simultaneous with the utterance time - Cicero's present. Let us therefore tentatively conclude that the appropriate meaning of the participle constitutam is a resultative-stative one, as already clearly indicated by Yonge's translation of the relevant fragment: "the constitution of the state, as it has been most wisely established by our ancestors".

This does not yet answer definitely the question whether the dative maioribus or the prepositional ablative a maioribus is to be preferred. As discussed above, the choice is not so easy as the simple distinction between the verbal and the stative passive might suggest. In environments in which the copular verb esse does not appear, the participle is free to appear in a structure in which the stativizer embeds the agentive vP; in principle both readings are equally possible as far as the system of the Classical Latin is concerned. The choice must therefore rely on other principles than grammatical acceptability. It seems that the stative reading, which strongly highlights the intimate connection between the constitutional practice of old times and the present state is to be preferred - the semantics of the passage points in this direction. We should therefore most probably choose the reading of the codex Monacensis 15 734: maioribus, with the concomitant semantics, accepting a reading unjustly rejected by modern editors.

\section{References}

\section{Texts: editions and translations}

M. Tullius Cicero, The Orations of Marcus Tullius Cicero, literally translated by C. D. Yonge, B. A. London. George Bell \& Sons, York Street, Covent Garden. 1891.

M. Tullius Cicero, The Orations of Marcus Tullius Cicero, literally translated by C. D. Yonge, B. A. London. Henry G. Bohn, York Street, Covent Garden. 1856. 
M. Tullius Cicero, M. Tulli Ciceronis Orationes, eds. A. C. Clark and W. Peterson Oxford: Oxord University Press, 1905-1918.

M. Tulliu s Cicero, Cum senatui gratias egit, Cum populo gratias egit, De domo sua, De haruspicum responsis,. ed. T. Maslowski, Teubner, Leipzig 1981.

M. Tullius Cicero, De finibus bonorum et malorum, ed. R. Reynolds. Oxford: Oxord University Press, 1998.

M. Tullius Cicero, Tusculanae disputationes. ed. M. Pohlenz. Teubner, Leipzig 1918.

\section{Secondary literature}

Alexiadou, A., M. Rathert, and A. von Stechow (eds.) 2003. Perfect Explorations. Berlin: Mouton de Gruyter

Anagnost op oulou, E. 2003. "Participles and voice". In: A lexiadou et al. (eds), 1-36 B h a t t, R. 1998. "Obligation and Possession". MIT Working Papers in Linguistics 32, 21-40.

Culicover, P. W., T. Wasow, and A. Akmajian (eds.). 1977. Formal Syntax. New York: Academic Press.

Dé chaine, R.-M. 1993. Predicates Across Categories: Towards a Category-Neutral Syntax. Ph.D. Dissertation, University of Massachusetts, Amherst

E m b i c k, D. 2004. "On the Structure of Resultative Participles in English". Linguistic Inquiry $35,355-392$.

Ernout, A. and F. Thomas. 1964. Syntaxe Latine. Paris: Klincksieck.

Freidin, R. 1975. “The Analysis of Passives". Language 51, 385-405.

Horvath, J. and T. Siloni. 2005. Adjectival Passives: Active Lexicon. Ms., Tel Aviv University.

Gueron J. and J. Le carme (eds). 2004. The Syntax of Time. Cambridge, MA.: MIT Press Kenstowicz, M. (ed.). 2001. Ken Hale: A life in language. Cambridge, MA.: MIT Press Kle i n, W. 1994. Time in Language. London, New York: Routledge.

Kratzer, A. 1998. “More Structural Analogies between Pronouns and Tenses'. In: Strolovitch D. and A. Law son (eds), 92-110

Kühner, R. and C. Stegmann. 1912. Ausführliche Grammatik der lateinischen Sprache, $B d$. 2.1. Hannover: Hahnsche Buchhandlung.

L e breto n, J. 1901. Études sur la langue et la grammaire de Cicéron. Paris: Librairie Hachette. Madvig, J. N. 1842. Opuscula academica altera. Hauniae: typis Schultzianis

M a y, J. M. (ed). 2002. Companion to Cicero. Oratory and Rhetoric. Leiden/Boston/Köln: Brill.

Menge, H. 2000. Lehrbuch der lateinischen Syntax und Semantik. Völlig neu bearbeitet von Thorsten Burkard und Markus Schauer. Darmstadt: Wissenschaftliche Buchgesellschaft.

Michael C. A. 2003. The Case for the Prosecution in the Ciceronian Era. Ann Arbor: The University of Michigan Press.

Mille r, D. G. 2000. "Gerund and Gerundive in Latin”. Diachronica 17, 293-349.

Partee, B. 1977. "John is Easy to Please”. In: Z a mpolli A. (ed.), 281-312.

Paslawska, A. and A. von Stechow. 2003. "Perfect Readings in Russian'. In: Ale x i a d ou et al. (eds): 307-362.

Pesetsky, D. and E. Torrego. 2001. “T-to-C Movement: causes and consequences." In: Kenstowicz M. (ed.), 355-426.

Pe sets ky, D. and E. Torreg o. 2004a. "Tense, Case, and the Nature of Syntactic Categories". In: Gueron J. and J. Le c a r me (eds.), 495-538

Pesetsky, D. and E. Torrego. 2004b. The Syntax of Valuation and the Interpretability of Features. Ms., MIT and Boston University

Powe11, J. and J. Paterson. 2004. Cicero the Advocate. Oxford: Oxford University Press. Pylkkänen, L. 2002. Introducing arguments. Ph.D. Thesis. Cambridge, MA.: MIT. 
Rothstein, S. 1999. "Fine-Grained Structure in the Eventuality Domain: the Semantics of Predicative Adjective Phrases and Be'. Natural Language Semantics 7, 347-420.

Strolovitch, D. and A. Laws on (eds). 1998. Proceedings of SALT VIII. GLSA Amherst. von Stechow, A. 1995. On the Proper Treatment of Tense. Ms., Universität Tübingen.

von Stechow, A. 1998. German Participles II in Distributed Morphology. Ms., Universität Tübingen.

von Stechow, A. 2001. The Janus Face of Aspect. Ms., Universität Tübingen.

W a s ow, T. 1977. "Transformations and the Lexicon.' In: C u l i c o ver et al. (eds), 327-360.

Zampolli, A. (ed.). 1977. Linguistic Structures Processing. Amsterdam: North-Holland. 
